\title{
Odešla legenda české balkanistiky Ivan Dorovský - vědec širokého záběru i básník stesku
}

\author{
Václav Štěpánek (Brno)
}

Na konci letošních prázdnin, 24. srpna, nás opustil prof. PhDr. Ivan Dorovský, DrSc., prof. h. c. V rodáku z egejské Makedonie ztratily Ústav slavistiky Filozofické fakulty Masarykovy univerzity, fakulta, univerzita i česká společnost významného vědce a oblíbeného vysokoškolského pedagoga, který po několik desetiletí formoval podobu české balkanistiky a slavistiky, odborníka mezinárodního významu, muže, jenž celý svůj aktivní život zasvětil neúnavnému bádání na poli česko-balkánských styků a bourání mýtů a stereotypů o Balkánu. V neposlední řadě v něm ztratily také básníka a plodného předkladatele z balkánských literatur. Profesor Ivan Dorovský patřil k slavné Ďurišinově škole literární komparatistiky, jejíž metody tvůrčím způsobem rozvíjel. Jako literární komparatista, literární historik a historik byl autorem řady knižních publikací a odborných studií uveřejněných u nás i v zahraničí, vyhledávaným diskutérem na mezinárodních konferencích zejména na Balkáně a v neposlední řadě i neúnavný propagátor česko-jihoslovanských styků, který se také nemálo zasloužil i o mladou makedonskou republiku a její vědecké renomé, za což byl po právu jmenován akademikem Makedonské akademie věd a umění.

Životní osudy Ivana Dorovského byly ještě mnohem košatější než jeho vědecké dílo. Narodil se v již desetiletí neexistující vesnici Čuka, ležící poblíž města Kostur (řecky Kastoria) v egejské Makedonii. Zde žil, do 25. 3. 1948, jako prosté dítě z chudé rolnické rodiny, bez otce, který, jako mnozí z této nepříliš úrodné horské oblasti, vydělával peníze až v daleké Austrálii. Otec odjel, když mu byl rok, takže si jej nepamatoval a poprvé jej uviděl až při své návštěvě Austrálie v roce 1970, kde mu také mohl představit svoji manželku Dagmar (jíž ale ř́ikal Danka), rodačku z hanáckých Otaslavic, později významnou literární historičku a pedagožku, docentku na Pedagogické fakultě Masarykovy univerzity.

V ono osudové datum byl ze své rodné vsi, a netušil, že navždy, spolu s desítkami dalších dětí evakuován, podobně jako tisíce jiných dětí žijících na území, které během občanské války v Řecku kontrolovala komunistická tzv. Řecká demokratická armáda, do Albánie a odtud pak dále do Jugoslávie a Československa. Tato dodnes kontroverzní a historiky nejednoznačně hodnocená akce tedy přivedla Ivana Dorovského do země, o níž před tím nikdy ani neslyšel a která se mu, ač si to tehdy nikdo z těch, kteří sem spolu s ním přišli, nemyslel, měla stát novým domovem. Většina z narychlo evakuovaných dětí s sebou neměla žádné dokumenty, o křestním listu nemluvě, a málokteré z nich také 
vědělo, kdy se vlastně narodilo. Ostatně, v prostředí, ve kterém do té doby žily, to ani nebylo zapotřebí. Všichni se tam přece znali. Když se tedy, jak piše ve své vzpomínkové knize $S$ domovem v srdci (Brno, 2014, s. 124), dostal Ivan do dětského záchytného tábora v brněnských Maloměřicích, uvedly do dokumentu pečovatelky jako datum jeho narození den, kdy přišel do tábora, tedy 18. květen. Svým způsobem měly pravdu, tehdy se totiž Ivan Dorovský narodil pro Československo, respektive pro Moravu. A protože malý Jani tušil, že je mu třináct let, zapsali k tomu květnovému datu jako rok jeho narození letopočet 1935. Teprve koncem sedmdesátých let mu jeho starší bratr přinesl výpis z kosturské matriky, v němž stálo, že se ve skutečnosti narodil 30. 7. 1934! Opustil nás tedy ve věku dožitých 87 let.

Uvědomíme-li si, čím vším Ivan Dorovský prošel, musíme před jeho úsilím etablovat se v nové vlasti jen hluboce smeknout. On sám sebe popisoval jako toho, kdo se $z$ dètského pastýre ovci a koz stal univerzitním profesorem. ${ }^{1}$ To by ale samo o sobě nebylo tak neobvyklé. Podobných případů bychom mohli najít více i mezi naší starší generací univerzitně vzdělaných lidí, nebot sebevědomý rolnický stav, jenž dříve, než zanikl „zásluhou“ komunistické kolektivizace zemědělství, dal české vědě hodně učenců. Proto by bylo výstižnější jeho charakteristiku doplnil ještě několika slovy, z nichž dvě by měla etnonymické charakteristiky: z dětského makedonského pastýre ovci a koz českým univerzitním profesorem, překladatelem a básnikem. Adjektivum makedonský je v této charakteristice velmi důležité. Ivan Dorovský totiž přišel do Československa bez znalosti jediného českého slova a hovořil vlastně pouze místním slovanským makedonským dialektem (spisovná makedonština v té době ještě ani neexistovala, a i kdyby existovala, v Řecku by se jí stejně nevyučovalo, jak je tomu konec konců dodnes, takže se jí teprve mnohem později vlastně musel učit), a ze školy uměl řecky. Svou vlastní pílí tedy ovládl jemu cizí český jazyk natolik dokonale, že jako dlouholetý redaktor různých periodik - mj. časopisů Universitas a Slovanský jih - či editor mnoha vědeckých sborníků a kolektivních monografií opravoval českým rodilým mluvčím jejich chyby. Navíc se stal také brilantním překladatelem, jenž českého čtenáře seznámil s díly celé plejády balkánských básníků, a to nejen makedonských nebo řeckých, ale i srbských, charvátských, bulharských a slovinských. A konečně, čeština se mu stala i jazykem jeho básnické tvorby. Ostatně, i v této vlastní zkušenosti lze nejspís hledat kořeny jeho vědeckého zájmu o literaturu exilu či diaspory, o autory bilingvní (dvojdomé), či o meziliterární společenství.

Jakkoli jubilant působil začínal své působení na filozofické fakultě v Brně v rámci Kabinetu balkanistiky a hungaristiky na Katedře historie a etnografie střední, jihovýchodní a východní Evropy filozofické fakulty brněnské univerzity a tudíž by se dalo předpokládat, že se bude ubírat ve stopách Josefa Macůrka a Josefa Kabrdy, jeho vzácných o generaci starších spolupracovníků, převážilo v odborné činnosti I. Dorovského, i pod vlivem Franka Wollmana, jehož byl také žákem, již od konce sedmdesátých let 20. století nad výzkumem historickým bádání literárněvědné, jemuž se také v tomto literárně vědném časopise budeme přednostně věnovat. ${ }^{2}$ Předmětem zájmu jubilanta byly v jeho

1 DOROVSKÝ, Ivan: $S$ domovem v srdci. Brno: Masarykova univerzita, 2014, s. 7.

2 O jeho historickém opusu viz např. HLADKÝ, Ladislav: Tradice brněnské balkanistiky a význam Ivana Do- 
prioritním vědeckém zájmu zpočátku, vzhledem k jeho původu i pochopitelně, zejména problémy makedonské literatury. Jeho práce se staly v tomto směru průkopnickými. ${ }^{3}$ Velkou láskou I. Dorovského byla zejména makedonská lidová poezie, a není divu, že celou řadu svých prací věnoval právě zkoumání procesů a kanálů, jimiž makedonská lidová slovesnost do českých zemí pronikala. Touto otázkou se zevrubně zabýval již v rozsáhlé kapitole své první velké monografie České země a Balkán: kapitoly z dějin česko-makedonských a makedonsko-českých styků (Brno, 1973) nazvané Makedonská lidová slovesnost v Čechách (s. 73-102). Tato jeho kniha je mj. i svědectvím toho, jak se jubilant ve vědeckém diskurzu dokázal rozkročit mezi historií, literární historií a částečně i etnologií. Navíc vztahová problematika, otázka kontaktů českých zemí, ale také Slovenska, Polska i Ruska se zeměmi Balkánu od této doby patřila neodmyslitelně k jeho tématům.

Četné práce I. Dorovského, zabývající se primárně makedonskou problematikou, ale měly i širší srovnávací aspekt slavistický a balkanologický, což je koncept, který je pro vědecké dílo Ivana Dorovského zásadním poznávacím znamením. K takovým pracím patří např. monografie Rajko Žinzifov. Vozdejstvije russkoj i ukrainskoj literatury na jego tvorčestvo (Brno,1988; také makedonsky jako Vozdejstvoto na ruskata i ukrainskata kniževnost vrz tvorčestvoto na Rajko Žinzifov, Skopje, 2003) aj.

Vzhledem ke znalosti řečtiny i k tomu, že jeho původní širší, byt macešskou vlastí bylo Řecko, věnoval se I. Dorovský také problematice novější řecké literatury. ${ }^{4}$ Recký literární faktor pak byl samozřejmě přítomen i ve všech jeho pracích širšího balkánského komparativního zaměření, zabývajících se 19. stoletím i novější dobou.

Ivan Dorovský se stal také bedlivým pozorovatelem a glosátorem i dalších balkánských, zejména ovšem jihoslovanských literatur. Časopisecky nebo ve sbornících zveřejňoval studie a statě o bulharské literatuře a dramatické tvorbě, o bulharských literárních tvưrcích a o česko-slovensko-bulharských kulturních stycích. Nevyhýbal se ani srbskému literárnímu prostoru, jejž vždy využíval pro své komparace, nicméně publikoval i několik příspěvků o žánrových a typologických otázkách samostatné srbské literatury, zejména poezie, at již avantgardy, o níž ve slovanském prostředí Balkánu hovoříme po první světové válce, ${ }^{5}$

rovského pro rozvoj této tradice. In: ŠTĚPÁNEK, Václav (ed.): Ivanu Dorovskému ad honorem. Brno: Muni Press, 2020, s. 43-50.

3 Např. jeho práce $O$ některých vývojových tendencích v poválečné makedonské próze. In: Sborník prací Filozofické fakulty brněnské univerzity. D, Rada literárněvědná 15, 1968, č. 17, s. 193-198; K charakteristice poválečné makedonské poezie. In: Sborník prací Filozofické fakulty brněnské univerzity. D, Rada literárněvědná 16 , 1969, č. 18, s. 152-162. Tyto a další práce mnohem později shrnul ve svazku Studii za balkanskiot literaturen proces vo XIX $i$ XX vek. Skopje: Makedonska akademija na naukite i umetnostite, 1992. $217 \mathrm{~s}$.

4 DOROVSKÝ, Ivan: Odysseus Kazantzakis. Universitas, 1973, č. 2, s. 25-32; Tradice a současnost v dile Giorgiose Seferise. In: Sborník prací Filozofické fakulty brněnské univerzity. D, Řada literárněvědná, 21, 1974, č. 23, s. 123-130 (jedná se o sumarizující studii o tomto řeckém nositeli Nobelovy ceny za literaturu, kterou I. Dorovský publikoval nedlouho po jeho smrti v roce 1971); Próza Gerasimose Grigorise. Světová literatura 18,1973 , č. 6 , s. 201-220.

5 DOROVSKÝ, Ivan: Balkánská avantgarda a některé jeji zvláštnosti. In: DOROVSKÝ, Ivan (ed.): Studie z literárněvědné slavistiky. Brno: Masarykova univerzita, 1999, s. 86-93. Metodologickými problémy zkoumání meziválečného literárního procesu se Dorovský věnoval ve studii $K$ metodologii studia meziválečného slovanského literárního procesu. Slavia 62, 1993, s. 351-356, v němž pozornost upínal mj. k otázce proletářské a sociální literatury v Srbsku a šířeji i v Jugoslávii a zabýval se i problematikou kruhu bělehradských surrealistů. 
tak o vývojových tendencích básnické tvorby po druhé světové válce. ${ }^{6}$ Pochopitelně ani v srbském a černohorském případě se nemohl vyhnout pracím o recepci děl srbské a černohorské prózy, poezie a dramatu do českého prostředí. ${ }^{7}$ Dlouhodobě se zabýval také zkoumáním charvátské moderny, česko-charvátskými literárními kontakty a mapoval recepci charvátské literatury v českých zemích. Důležitá je v tomto smyslu zejména jeho menší monografie Dramatik Miroslav Krleža (Brno, 1993), v níž se kromě analýzy dramatu jako zásadního žánru Krležovy tvorby věnoval právě recepci umělcových dramat v českém prostředí. Jihoslovanské drama vůbec bylo jeho srdeční záležitostí, jak o tom svědčí nakonec i kniha Dramatické umění jižnich. Slovanů I. (1918-1941) (Brno, 1995), v níž vlastně vědomě navázal na bádání svého učitele Franka Wollmana. Obecně lze tedy říci, že zkoumání recepce jihoslovanských literatur v českém prostředí patřilo ke stálicím jeho vědecké tvorby. Své výsledky v tomto směru směru pak zobecnil v monografii Recepce literatury jižních Slovanů u nás (Boskovice, 2003).

Nedílnou součástí vědecké práce Ivana Dorovského ovšem byla také literárněvědná lexikografická činnost. Jako první v řadě dalších je v tomto případě nutno zmínit jeho spoluautorství na slovníku řeckých spisovatelů (Slovnik spisovatelů. Řecko. Praha, 1975; 2. vydání Praha, 2006). Již pod jeho vedením pak vznikl slovník bulharských spisovatelů (Slovnik spisovateli̊. Bulharsko. Praha, 1978), v jehož rámci publikoval zásadní a u nás dodnes nepřekonanou studii o vývoji bulharské literatury od jejích počátků do doby vydání této publikace. Jeho úsilí, aby ve slovníku byli uvedeni někteří literární tvůrci zejména 19. století jako tzv. dvojdomí či mnohodomí (což jsou jeho vlastní termíny pro autory patřící do dějin více národních literatur), nebot podle něj přináležejí jak do dějin bulharské, tak i makedonské literatury, se tehdy setkalo se zásadním odporem bulharských historiků a literárních historiků. O slovníku, jeho koncepci i jeho editorovi se jednalo dokonce i na nejvyšších vládních úrovních československo-bulharských a československo-jugoslávských. ${ }^{8}$ Práce nicméně nakonec po mnoha protivenstvích vyšla.

Na svou lexikografickou činnost ze sedmdesátých let 20. století navázal Ivan Dorovský i později. V roce 1984 vedl autorský tým při práci na skriptech nazvaných Slovnik slovanských spisovateli̊ (Praha, 1984), asi nejvýznamnějším počinem v tomto směru pak bylo

6 DOROVSKÝ, Ivan: K některým vývojovým tendencím poválečné básnické tvorby jugoslávských národů. In: Sborník prací Filozofické fakulty brněnské univerzity. D, Řada literárněvědná 41, 1995, č. 43, s. 133-142; týž: O nekim sličnostima $i$ razlikama u posleratnoj lirici balkanskih slovenskih naroda. In: Naučni sastanak slavista u Vukove dane, 24, Beograd 1995, s. 5-12.

7 Zdůraznil bych zde např. jeho práci Recepce dila Mihaila Laliće v Československu. In: Sborník prací Filozofické fakulty brněnské univerzity. D, Řada literárněvědná 33, 1986, č. 35, s. 99-105, či Sima Milutinović Sarajlija u Čechů a Slováků. In: Sborník prací Filozofické fakulty brněnské univerzity. D, Řada literárněvědná 40, 1993, č. 42, s. 33-44. Zajímavé a komplexní zhodnocení přínosu Josefa Holečka pro rozvoj česko-černohorských vztahů přičinil I. Dorovský v předmluvě k Holečkově práci o Marku Miljanovovi Popovićovi, která vyšla v černohorském překladu v edici, jež přibližuje černohorskému čtenáři díla zahraničních osobností, které se tak či onak zabývaly Černou Horu. Viz Prijatelj i istoriograf Crne Gore Josef Holeček. In: HOLEČEK, Josef: Marko Miljanov u svom vrmenu. Podgorica: Kulturno-prosvjetna zajednica, 1995.

8 O problémech, které měl I. Dorovský v tomto směru i o traktování jeho díla ve vysokých kruzích komunistických funkcionářů viz např. PELIKÁN, Jan - VOJTĚCHOVSKÝ, Ondřej: Makedonská otázka ve vztazich mezi Československem a Jugoslávii v 70. a 80. letech 20. stoleti. In: ŠTĚPÁNEK, Václav (ed.): Ivanu Dorovskému ad honorem. Brno: Muni Press, 2020, s. 149-170, zejména pak na s. 158-159. 
jeho editorství Slovniku balkánských spisovateli (Praha, 2001), v němž připravil úvodní přehledová hesla jednotlivých balkánských literatur a spolu s autorem těchto řádků, tehdy lektorem češtiny na Filologické fakultě Bělehradské univerzity, a s tehdy začínajícími mladými pracovníky Ústavu slavistiky Filozofické fakulty Masarykovy univerzity Pavlem a Elenou Krejčovými sestavil většinu hesel.

To, co Ivan jako člen a propagátor slovenské komparatistické školy založené Dionýzem Ďurišinem (1929-1997) tak těžce prosazoval během práce na slovníku bulharských spisovatelů, tedy zkoumání oné dvoudomosti či mnohodomosti balkánských literárních tvůrců zejména (ale nejen) 18. a 19. století, se stalo základem pro jeho široce komparativní vědeckou práci, jíž v posledních třiceti letech zúročil svá dosavadní bádání. Vyznačovala se snahou proniknout do problematiky meziliterárních společenství v balkánském prostředí, komparací různých etap jihoslovanských literatur s přesahy do neslovanských celobalkánských či dokonce mediteránních souvislostí, zkoumáním mikroliteratur, diaspory, exilu i společných kořenů jihoslovanské (a šřřeji i slovanské) vzdělanosti. ${ }^{9}$ Tyto tendence jsou patrné jak v jeho klíčové balkanistické práci nazvané Balkán a Mediterán: literárně historické a teoretické studie (Brno, 1997), tak v řadě dalších monografií sestavených většinou z několika obsáhlých studií, počínaje prací Balkánské meziliterárni společenstvi (Brno, 1993), přes díla Slované a Evropa (Brno, 2000), Slovanské meziliterárni shody a rozdí ly (Brno, 2004), až po svazky Slovanské literatury a dnešek (Brno, 2008) a Studia balkanica et slavica I a II (Brno, 2001 a 2016) v nichž autor dává nahlédnout také do své neobyčejně bohaté a fundované recenzní činnosti, jinak samozřejmě roztroušené v mnoha periodikách. Recenze a zprávy o próze, poezii i dramatu balkánských národů, ale i o vědeckých pracích zabývajících se touto tematikou či o nejrůznějších konferencích činí v bibliografii I. Dorovského několik set položek! ${ }^{10}$

Kromě tohoto mnohovrstevnatého vědeckého díla Ivana Dorovského je ale zapotřebí vyzdvihnout i jeho "praktickou“ literární činnost. Obohatil totiž českou literaturu o množství překladů prakticky ze všech jihoslovanských literatur a z literatury řecké. Překládal především poezii a povídkovou tvorbu. Až do poloviny devadesátých let 20. století je ale většina jeho překladů bohužel roztroušena po nejrůznějších periodikách. Poté ovšem začal v rámci Společnosti přátel jižních Slovanů, již založil vzápětí po roce 1989, vydávat jednak antologie z překladů poezie a krátké prózy jihoslovanských literatur, vedle toho však i samostatné sbírky poezie jihoslovanských tvůrců. První kniha v této řadě vyšla v roce 1995. A byla to antologie moderní slovinské poezie, nazvané Orfeus $v$ dešti, následovaná ještě v témže roce vlastní antologií (a překladem) makedonské poezie Modré nebe nad Ochridem. V roce 1996 pak vydal doposud nejrozsáhlejší českou antologii moderní srbské básnické tvorby (obsahuje 229 básní 76 srbských básníků) Nekonečný

9 Zevrubněji o Dorovského metodách práce a termínech dvojdomosti a meziliterárních společenství v př́ispěvcích Ivo Pospíšila Ivan Dorovský jako slavistika a komparatista a Miroslava Kouby Interpretace bulharsko-makedonského obrozeni v kontextu teorie o meziliterárních společenstvích a literárni dvojdomosti. In: ŠTĚPÁNEK, Václav (ed.): Ivanu Dorovskému ad honorem. Brno: Muni Press, 2020, s. 31-42 a 83-100.

10 Bibliografii jeho děl nalezneme v několika publikacích: DOROVSKÝ, Ivan: Bibliografie. Brno: Společnost přátel jižních Slovanů, 2000. DOROVSKÝ, Ivan: Bibliografie. In: Slavista s duší básníka. Sborník k sedmdesátinám Ivana Dorovského. Brno - Boskovice: Společnost př́tel jižních Slovanů v České republice František Šalé - Albert, 2005. 
modravý kruh. Ve všech těchto antologiích využil kromě svého překladatelského umění také služeb etablovaných básníků a překladatelů. Později ale při sestavování antologií dával příležitost prokázat překladatelský talent také studentům jednotlivých jihoslovanských filologií, z nichž se mnozí poté stali i uznávanými a plodnými překladateli. Tak vznikly např. antologie charvátské povídky 20. století V objetí reky (Boskovice, 2002), antologie moderní slovinské krátké prózy Vně hranic (Boskovice, 2002), antologie moderní bulharské povídky Narodili jsme se jako draci (Boskovice, 2003) nebo Malá krabička: 100 nejkratších srbských povidek 20. stoleti (Boskovice, 2002). Sám jubilant pak sestavil a přeložil výbory z poezie makedonských básníků Kosty Racina, Rista Lazarova, Cane Andreevského a Gane Todorovského, buharského básníka Văta Rakovského, slovinského básníka Edvarda Kocberka, charvátských poetů Vesny Parunové a Anđelka Vuletiće a srbských básníků Desanky Maksimovićové a Stevana Tontiće, k tomu přidal i několik sbírek aforismů Slovince Žarka Petana.

To, že Ivan Dorovský překládal zejména poezii, není samozřejmě náhoda. Ivo Pospíšil jej totiž již před lety nazval „vědcem s duši umělce“. ${ }^{11}$ A umělecká duše Ivana Dorovského se z přetlaku vědecké práce nedokázala vyrovnat jinak než básněmi. Jeho první drobná sbírka, Stesk po jihu, vyšla již v roce 1985 k jeho padesátinám. Teprve za dvacet let, v roce 2005 ji následovala druhá sbírka, Kořeny (Boskovice, 2005), a později se, opět s odstupem, prezentoval sbírkami Hledám slova (Brno, 2013), Já se tam nevrátím (Brno, 2015) a konečně poslední, nazvanou příznačně Až jednou (Brno, 2019). Dalo by se říci, že všechny jubilantovy sbírky mají jistá společná témata - lásku k manželce, k zemi, v níž kdysi nalezl nový domov, k Hané, nicméně tím zásadním leitmotivem jeho poezie, tím, čím jeho duše přetéká, je to, co tak pregnantně vyjádřil již v názvu své první sbírky: Stesk po jihu.

Jakkoli totiž Ivan Dorovský nalezl na Moravě nový domov, z lásky k němuž se dokázal ve svých básních tak pěkně vyznat, jakkoli si zde vybudoval i svou obdivuhodnou vědeckou kariéru, a jakkoli v Prostějovsku, rodném kraji své manželky, nalezl i novou krajinu svého srdce (vyznal se z ní v zřejmě posledním článku, který mu za života vyšel, v rubrice Krajina srdce v Časopise pro ochranu přírody a krajiny Veronica), ${ }^{12}$ své makedonské kořeny nemohl zapřít. A nemohl také zapomenout. „Ve své druhé vlasti / se celý život učím žit / s touhou po rodné vsi, / s bolestí v srdci, / také s nespavosti / a s hlavou často bolavou. "13 Nemohl zapomenout na svoji rodnou vesnici, na společenství, v němž vyrůstal. Svůj ztracený ráj, svůj domov viděl stále i tam na jihu, kde žil prvních třináct let svého života: „Domov je maminka / jež čeká na prahu s krajicem chleba / Domov - to jsou hry mého dětstvi / domov je cinkáni talíru / které maminka pokládá na stůl / je úkrytem nikdy neodhalených tajemstvi / Domov je otcouský domek / jenž se již dávno změnil v ruiny / na nichž rostou trávy a keře / a vedle již zaházené studny / vyrostl obrovský ořešák / Na náš domek se lze dívat / nelze však do něj vejit / ani z něho vyjít / právě proto / že nemá dveře / Dveřmi jsou denni východy slunce /

11 POSPÍŠIL, Ivo: Balkanolog, slavista a komparatista s duši umělce. K šedesátinám prof. PhDr. Ivana Dorovského, DrSc. In: DOROVSKÝ,Ivan: Bibliografie. Brno: Společnost přátel jižních Slovanů, 1995, s. 12.

12 DOROVSKÝ, Ivan: Kraj, který miluji. Veronica, časopis pro ochranu př́rody a krajiny 35, 2021, č. 2 , s. 32-33.

13 DOROVSKÝ, Ivan: Kořeny. Boskovice: František Šalé - Albert, 2005; báseň Rodná ves, s. 11. 
a okny nočni obloha / Domov je totéž co vlast / je to bájná Arkádie / Domov je největši slast / to je má ubohá Makedonie / [...]. " ${ }^{14}$ Byl tedy, abychom použili jeho vlastní vědecké terminologie, člověkem dvojdomým, v němž po tom druhém, ztraceném, domově zůstával hluboce skrytý bol. „Ti moji lidé [... žijicí v mnoha zemich Evropy a světa a téměr na v̌̌ech kontinentech ...] se již nikdy společně nesetkaji. Někteři z nich v průběhu desetiletí navštívili Čuku a svou vlast, v niž se narodili, většina z nich však už svou rodnou obec nespatřila. Zưstala jim pouze touha a nostalgie. A také vzpominky [...]. "15 Zůstával v něm Stesk po jihu. Stesk a nostalgie, tak dobře patrné v názvu sbírky Já se tam nevrátím (Brno, 2015) a v ní zahrnuté básni Ozvěna:

Ležím v trávě a hledím $k$ obloze.

Mohu o všem přemýšlet.

Bez obav, bez závazki̊

vůč komukoliv,

vůči čemukoliv.

$V$ tom tichu mi v hlavě zni:

rodný kraj?

A ozvěna odpovidá:

tam už se nikdy nevrátís.

Zde je tvůj domov,

peklo $i$ ráj.

Zde je nyni můj rodný kraj.

Zde je můj domov, mé bezpeči.

Až budu vychládat,

dejte mi do rukou kámen ze skály

vyhřatý balkánským sluncem.

Bude mne věčně zahř́vat.

Odpust, Františku Halasi,

do Čuky se už nikdy nevrátím,

zde dožiji svi̛j

leden $i$ máj.

Poslední verše té básně jsem se odvážil také zveřejnit na Ivanovu parte. I proto, že se ta teskná báseň naplnila a je smutně pravdivá. Ivan Dorovský tedy navždy spočinul ve svém novém domově. $\mathrm{V}$ domově, v němž zanechal nesmazatelnou stopu a kde zůstane zachován v paměti stovek studentek a studentů slavistických i jiných oborů a mnoha svých kolegů.

14 Tamtéž, báseň Domov, s. 13.

15 DOROVSKÝ, Ivan: $S$ domovem v srdci. Brno: Masarykova unverzita, 2014, s. 25. 
doc. PhDr. Václav Štěpánek, Ph.D.

Ústav slavistiky

Filozofická fakulta, Masarykova univerzita

Arne Nováka 1, 60200 Brno, Česká republika

v.stepanek@int-cz.com 